TITLE:

Identification of Bifurcate Paraocular Process and Postocular Filamentary Tuft of Facetotectan Cyprids (Crustacea : Maxillopoda)

AUTHOR(S):

Ito, Tatsunori; Takenaka, Makoto

CITATION:

Ito, Tatsunori ...[et al]. Identification of Bifurcate Paraocular Process and Postocular Filamentary Tuft of Facetotectan Cyprids (Crustacea : Maxillopoda). PUBLICATIONS OF THE SETO MARINE BIOLOGICAL LABORATORY 1988, 33(1-3): 19-38

ISSUE DATE:

1988-08-20

URL:

http://hdl.handle.net/2433/176150

RIGHT: 


\title{
Identification of Bifurcate Paraocular Process and Postocular Filamentary Tuft of Facetotectan Cyprids (Crustacea: Maxillopoda)
}

\author{
By \\ Tatsunori Itô \\ Seto Marine Biological Laboratory, Kyoto University, \\ Shirahama, Wakayama 649-22, Japan \\ and \\ Makoto Takenaka ${ }^{1)}$ \\ Ushimado Marine Laboratory, Okayama University, Ushimado, \\ Okayama 701-43, Japan \\ With Text-figures $1-11$
}

\begin{abstract}
The ultrastructure of the bifurcate paraocular process and postocular filamentary tuft in an undescribed form of facetotectan cyprid from the North Pacific was examined using TEM. The bifurcate paraocular process is proximally accompanied by cilia that give rise to complex, lamellar structures, and appears to be an external portion of the organ of Bellonci, which is well known in cirripedes and some other crustaceans. The postocular filamentary tuft is an aggregation of filamentary extentions arising from cells that are part of a prominent organ located posterior to each compound eyc. This organ is probably a gland, similar in position and cell composition to the cement gland known in cirripede cyprids, though its actual function is still unclear.
\end{abstract}

Bifurcate paraocular processes and postocular filamentary tufts of "cypris y" (a post-naupliar stage of the facetotectan Crustacea) were first described by Itô (1985) based upon observation of three Hansenocaris species from Japan. Although additional observations and intensive discussions were directed to these enigmatic structures, their identities have not become clear (Itô, 1986b, 1986c, 1987a; Grygier, 1987c). As it was obvious that the lack of micro-anatomical knowledge caused this uncertainty, we have examined these structures using a transmission electron microscope. The present paper deals with the results obtained from this study.

Facetotectan nauplii (nauplius y) were collected from plankton samples taken with a small plankton net $(30 \mu \mathrm{m} \mathrm{mesh})$ in Tanabe Bay $\left(33^{\circ} 42^{\prime} \mathrm{N}, 135^{\circ} 21^{\prime} \mathrm{E}\right)$ near the Seto Marine Biological Laboratory on the Pacific coast of Japan. The collected nauplii were individually lsept in glass dishes filled with filtered sea-water until they metamorphosed into the "cypris $y$ " stage. The glass dishes were placed in a constant-temperature room maintained at $19^{\circ} \mathrm{C}$. Exuviae of the reared nauplii were pipetted immediately whenever they were noticed; they were examined using a phase-contrast microscope to

1) Present address: Komoike 2-7-6, Kojima, Kurashiki, Okayama 711, Japan.

Publ. Seto Mar. Biol. Lab., 33(1/3), 19-38, $1988 . \quad$ (Article 2) 
identify the species and to determine the developmental stage. Five cyprids that metamorphosed from nauplii of type XI (Itô, 1987c) in November and December, 1986, were fixed for TEM examination. They were all an undescribed form of Hansenocaris, which resembles H. pacifica Itô, 1985, in general appearance but is smaller. A last-stage nauplius that internally had a well-developed cyprid body with compound eyes, and that was estimated to be at most 24 hours before the molt to the cyprid, was also fixed for TEM examination.

The specimens were pre-fixed for 1.5 hours with $2.5 \%$ glutaraldehyde buffered with $0.2 \mathrm{M} \mathrm{Na-}$ cacodylate ( $\mathrm{pH} 7.4$ ), followed by three rinses in the Na-cacodylate buffer. While keeping them cool, these pre-fixed specimens were transferred to the Ushimado Marine Laboratory for further treatments and TEM study. The specimens were post-fixed in $1 \%$ osmium tetroxice dissolved in the same buffer for 1.5 hours and then dehydrated through ethanol and propylene oxide and embedded in an epoxy resin (TAAB embedding resin). The cyprid specimens were cut with glass knives into ultrathin, serial sections; horizontal, cross, and sagittal sections were made. The naupliar specimen was cut into ultrathin, cross sections. The ultrathin sections were stained with $1 \%$ alcoholic uranyl acetate and $0.1 \%$ lead citrate solutions, and were studied in an Hitachi $\mathrm{H}-500 \mathrm{H}$ electron microscope at an accelerating voltage of $75 \mathrm{kv}$.

\section{Results}

\section{Bifurcate Paraocular Process.}

The bifurcate paraocular process arises from the ventral surface of the cephalon, close to the medial side of the incurved rim of the carapace. It is located between the first antenna and compound cye (Fig. 1A), very close to the lateral base of the first antenna but separated from it by a gap. It consists of a very short stalk and two apical branches, i.e., anterior and posterior branches (Fig. 2A). In some cross sections, what appeared to be a few papillary "processes" were recognized to arise from either the medial or posterior base of the stalk (Figs 2A, 3B). These "processes" are very small, at most $1.1 \mu \mathrm{m}$ long, with no noticeable internal structures. They are probably cross views of corrugations on the stalk.

The exterior of the paraocular process is entirely covered by thin cuticle. There is no difference in the internal structure of the two branches. No nuclei are found within them. Some cellular processes, which are delimited by plasma membranes and which extend from within the cephalon through the stalk, are recognized within both branches (Fig. 3A). These cellular processes contain small numbers of mitochondria, small vacuoles, and rough ER (Fig. 3). Some cilia with a $9+0$ microtubule array are recognized within the stalk as well as within the proximal portions of the branches (Fig. 3B). Other cilia or ciliary projections without a clear arrangement of $9+0$ microtubules are also present within the stalk as well as within both branches; they extend toward the apexes of the paraocular process as far as midlength. Some of the cilia and ciliary projections within the stalk seem to extend from within the cephalon as described later.

The paraocular process is closely associated with a mass of complex, lamellar or reticulate structures that is present inside the cephalon anterior to each compound eye (Figs 1B, 2). In lateral view, this lamellar mass is almost droplet-shaped, lying with its spherical portion anteriorly (Fig. 2). It measures approximately $11 \mu \mathrm{m}$ long, $6 \mu \mathrm{m}$ high, and $6 \mu \mathrm{m}$ wide. The lamellar mass is a little concave midventrally 


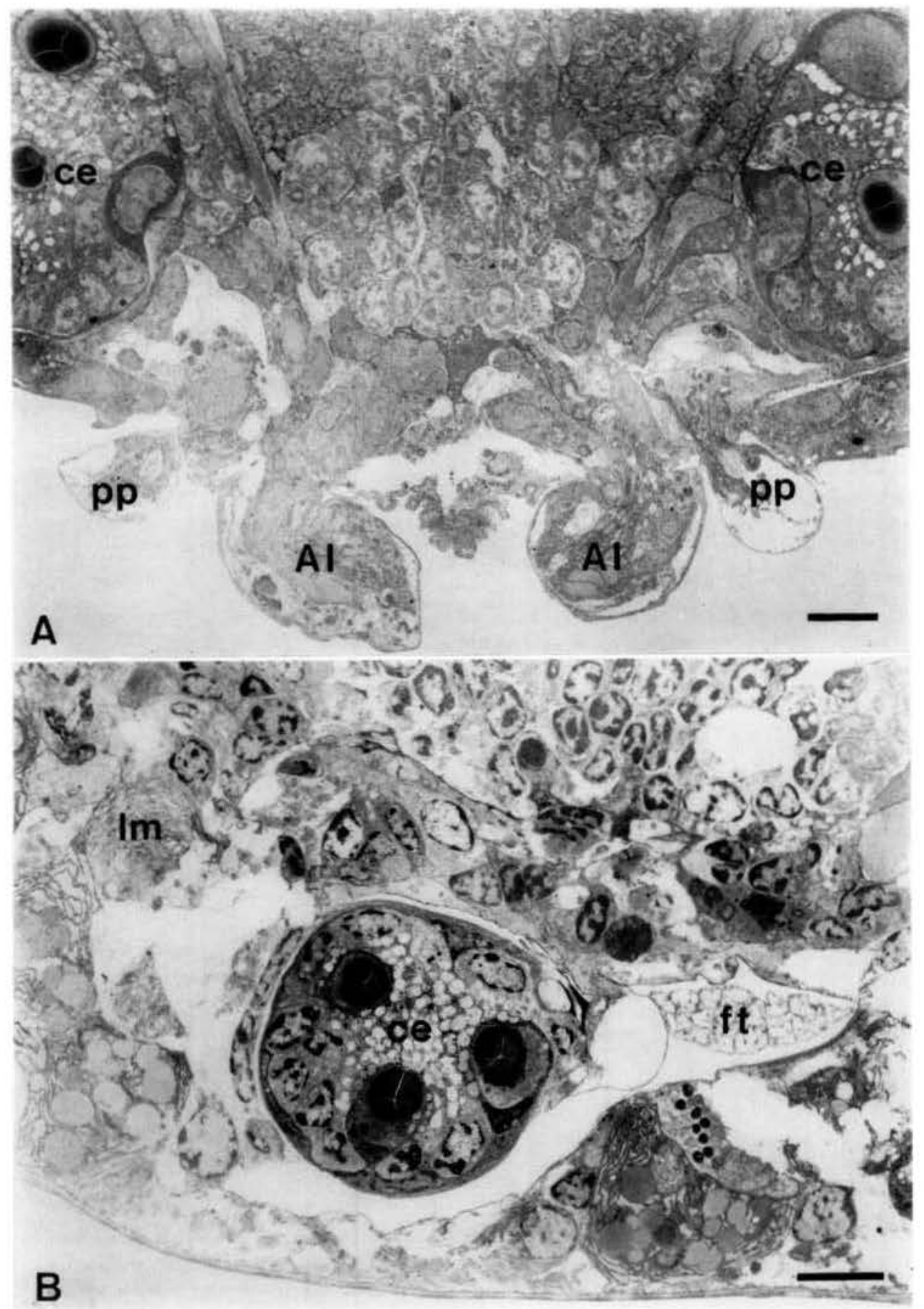

Fig. 1. Arrangement of paraocular process and filamentary tuft. A. Cross section showing paired paraocular processes (upper $=$ dorsal) ; B. Horizontal section around a compound eye, showing a lamellar mass of the organ of Bellonci and a filamentary tuft (left= anterior). AI, first antenna; ce, compound eye; fit, filamentary tuft; Im, lamellar mass; pp, paraocular process. Scale: $5 \mu \mathrm{m}$. 

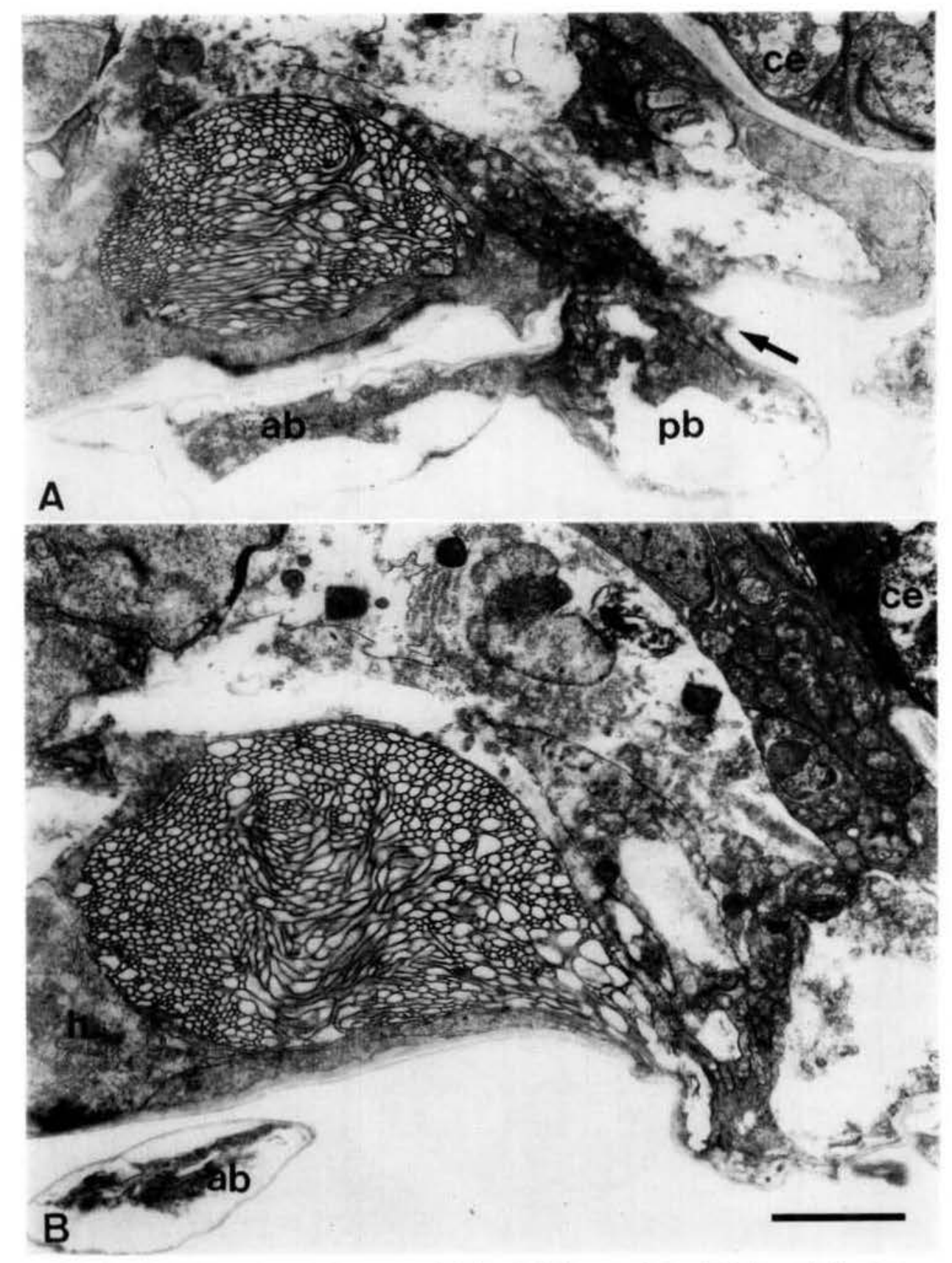

Fig. 2. Sagittal sections of the organ of Bellonci (left=anterior). Cells located dorsal to the lamellar mass are damaged artificially. A. Bifurcate paraocular process with a small "process" (arrowed) posteriorly; B. Mass of lamellar structures extending to base of paraocular process. ab, anterior branch of paraocular process; ce, compound eye; $\mathrm{pb}$, posterior branch of paraocular process; $\mathrm{h}$, possible hypodermal cell. Scale: $3 \mu \mathrm{m}$. 


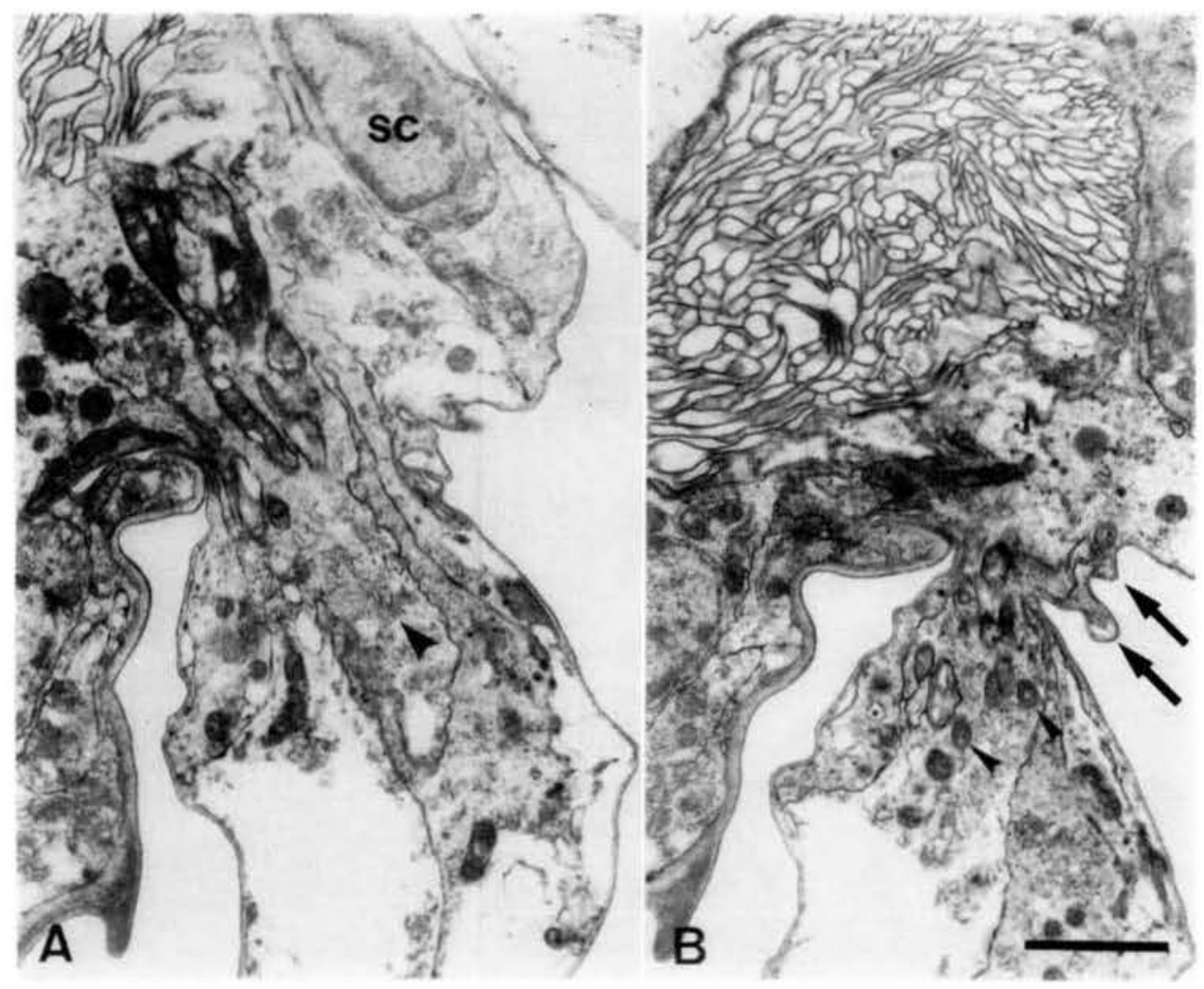

Fig. 3. A. Cross section of the organ of Bellonci, with posterior branch of its paraocular process (right $=$ medial; arrowhead indicating rough ER); B. Cross section of the organ of Bellonci, with two "processes" attaching onto medial side of its shaft (arrowed) (arrowheads indicating cilia). Scale: $2 \mu \mathrm{m}$.

(Fig. 4A) and tapers posteriorly to reach the base of the paraocular process (Fig. 2B). A number of cilia with a $9+0$ microtubule arrangement are incorporated among the lamellar structures (Fig. 4A). The cilia appear to be directly connected with the lamellar structures, at least in part (Fig. 4D). It is occasionally recognized that a few microtubules occur within tubular areas encircled by lamellae (Fig. 4D). Hence, what appeared to be lamellar or reticulate structures are projections of cilia. Central fibrils are recognized between lamellar structures (Fig. 4C). No rootlets of the cilia are detected (Fig. 4B).

The cells that give rise to these cilia with projections are found around the mass of lamellac. However, some cells, especially ones located dorsal and posterior to the lamellar mass, appeared to be damaged artificially (Fig. 2B). It is likely that the osmotic pressure of the fixative was too low and some fragile cells fragmented. Above the lamellar mass is a wide space in which fragments of such cells are dispersed. This wide space is probably also an artifact, although a narrow vesicle might have been present originally. Hence, the precise arrangement of all the cells that give rise to the cilia with processes could not be determined. Nor could a connection 


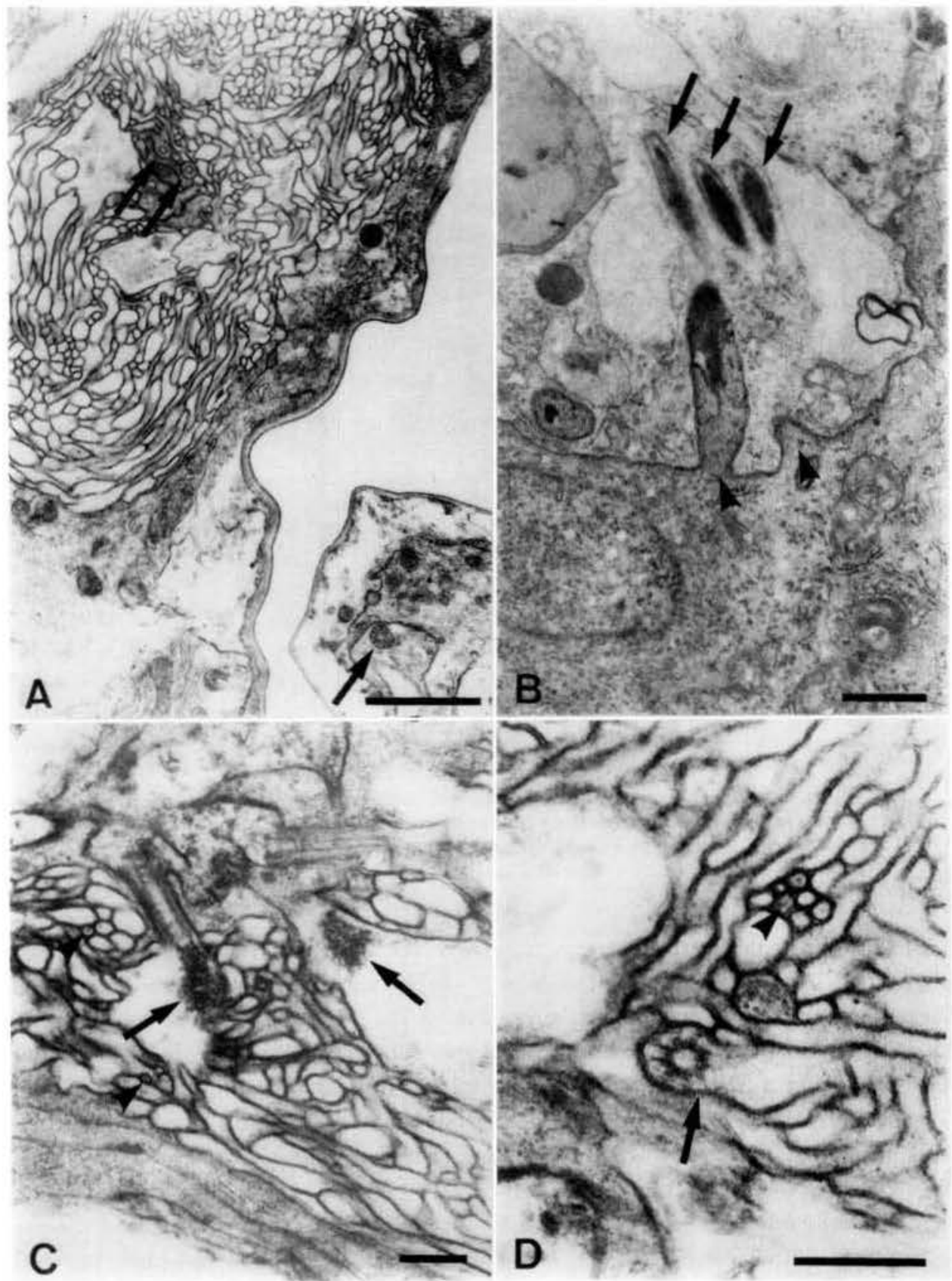

Fig. 4. Sections of the organ of Bellonci. A. Cross section showing cilia (arrowed) within lamellar mass and anterior branch; B. Horizontal section of a cell with cilia (indicated by arrowheads) located dorsal to base of paraocular process (three arrows indicating cilia of a separate cell); C. Longitudinal sections of two cilia continuous with lamellae (arrowheads indicating central fibrils). D. Cilium continuous with lamellac (arrowed) (arrowhead indicating microtubules within a tubular lamella/ciliary projection). Scales: A, $2 \mu \mathrm{m}, \mathrm{B}, 1 \mu \mathrm{m}$. C, D, $0.5 \mu \mathrm{m}$. 
between these cells and the central nervous system be traced.

A few nucleate cells lie against the posterodorsal face of the lamellar mass. They appear to extend their cytoplasm, together with cilia, into the paraocular process (Fig. 3A). Attached to the ventral integument of the cephalon are some other, noticeable cells whose somatic portions with the nucleus are located either medial or anterior to the lamellar mass and extend beneath the latter toward the paraocular process (Fig. 2B); some of them appear to penetrate into the paraocular process along its cuticle. The perinuclear cytoplasm of these cells contains rough ER. They are probably hypodermal cells or support cells. Apparent support cells are arranged to surround the space above the lamellar mass. They appear to make a vesicle in which the lamellar mass was originally placed, though its precise form is uncertain due to artifacts.

\section{Postocular Filamentary Tuft}

A filamentary tuft is located posterior to each compound eye (Fig. 1B), deeply inserted between two, finely wrinkled, papillary processes, which are remnants of the naupliar second antenna and mandible (Fig. 5A). Sixteen filaments constitute each tuft. These filaments, which are about $30 \mu \mathrm{m}$ long, appear to arise from some of the compactly aggregated, prominent cells that occupy a fairly large portion of the cephalon behind the compound eye. The whole of the external filaments and these associated cells will be referred to as the "filamentary tuft complex." The general structure of the filamentary tuft complex is shown in Fig. 6 diagramatically.

The filamentary tuft complex consists of two cell types that are typically characterized by the possession of either secretary granules or dense mitochondria. They will be referred to as "granular cells" for the former, "mitochondria cells" for the latter.

The main portion of the aggregation of these cells is almost spherical, measuring about $25 \mu \mathrm{m}$ in the maximum diameter. This spherical part is partially appressed to the posterior side of the compound eye. The cells taper medially and aggregate to form a column, which immediately turns toward the compound eye, and then extends downwards at a place just posterior to the compound eye. The filaments emerge from a level a little below or distal to the last flexure (Fig. 6, see also Fig. 10A).

The filamentary tuft complex consists of nine granular cells, which give rise to the filaments, and eight mitochondria cells. Somatic portions of these cells may be columnar or pyriform in general appearance. The mitochondria cells are smaller than the granular cells. In some lower, horizontal sections of the spherical main part of the filamentary tuft complex, they appear as a rosette of prominent cells with nuclei (Fig. 5B).

The granular cells have highly developed, rough ER in their perinuclear cytoplasm (Fig. 5B). The rough ER generally appears, especially in horizontal sections, to be arranged concentrically. Spherical mitochondria are also present within the perinuclear cytoplasm, but these mitochondria are not distributed as widely as those 


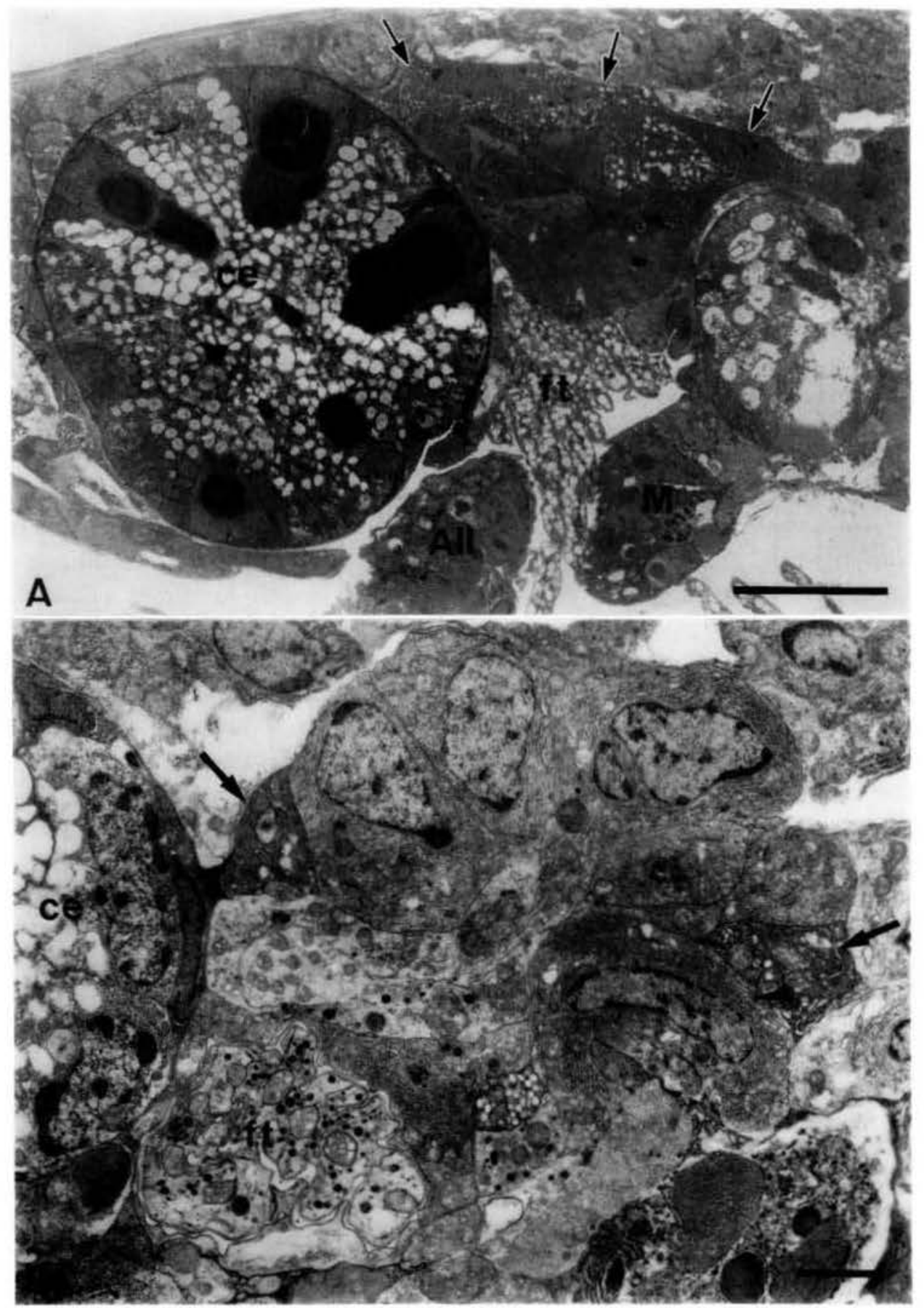

Fig. 5. A. Sagittal section showing situation of filamentary tuft complex (left=anterior; arrows indicating dorsal margin of filamentary tuft complex); $\mathrm{B}$. Horizontal section of filamentary tuft complex with rosett-like arrangement of cells (upper=lateral; left= anterior; arrows indicating mitochondria cells, arrowhead indicating rough ER in a granular cell). ce, compound eye; ft, filamentary tuft; AII, remnant of second antenna; M, remnant of mandible. Scales: A, $10 \mu \mathrm{m}$. B, $2 \mu \mathrm{m}$. 

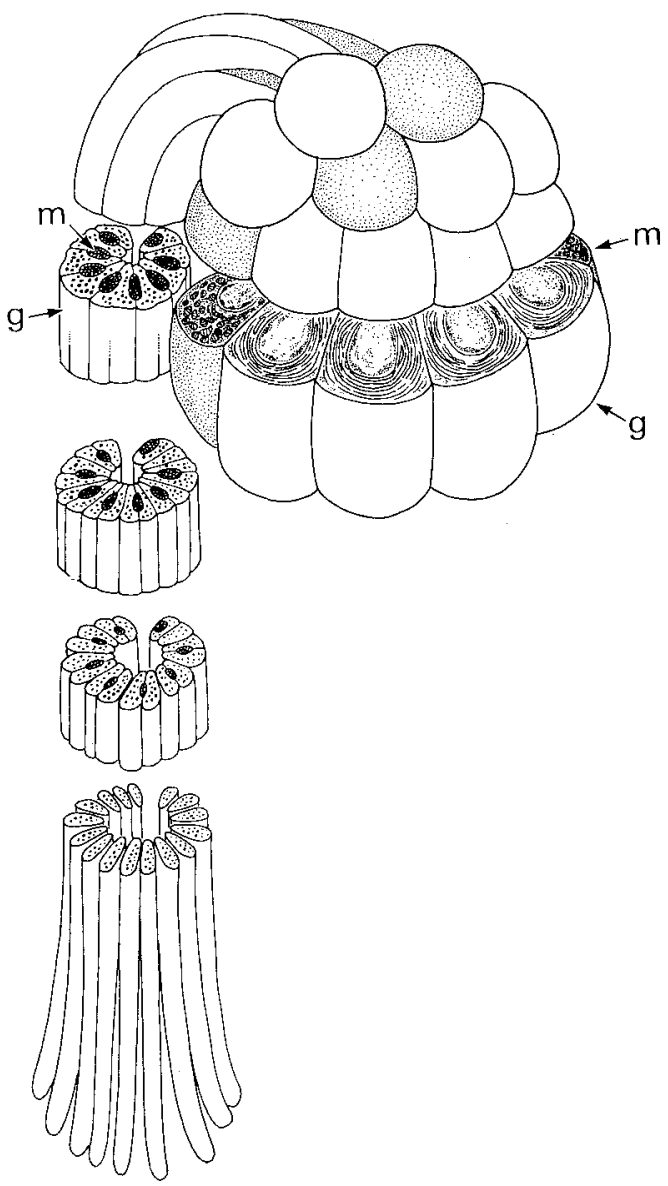

Fig. 6. Diagram of filamentary tuft complex. g, granular cell. $\mathrm{m}$, mitochondria cell.

in mitochondria cells. Electron-dense granules are present in a region a little dorsal to the nucleus and disperse toward the apical filaments (Fig. 7). The granules are probably rod-shaped and almost uniform, at most $0.5 \mu \mathrm{m}$ long, $0.15 \mu \mathrm{m}$ in diameter. The differences in their size and shape appeared in the sections could be due to differences in their orientation when sectioned. No reticulate structure is recognized within these granules. As described later, the granules apparently penetrate into each filament as far as midlength. It is uncertain whether the granular cells have axons.

Somatic portions of most mitochondria cells appear to wedge themselves between granular cells (Fig. 5B). They are located at dorsal, anterior, and posterior portions of the spherical part of the filamentary tuft complex. Some mitochondria cells are located medially. The apex of each mitochondria cells reach nearly to the base of filaments (Fig. 7A). From the bottom of each of these cells arises a process that appears to be an axon and apparently extends toward the rear (Fig. 9B), though their terminals cannot be determined. 


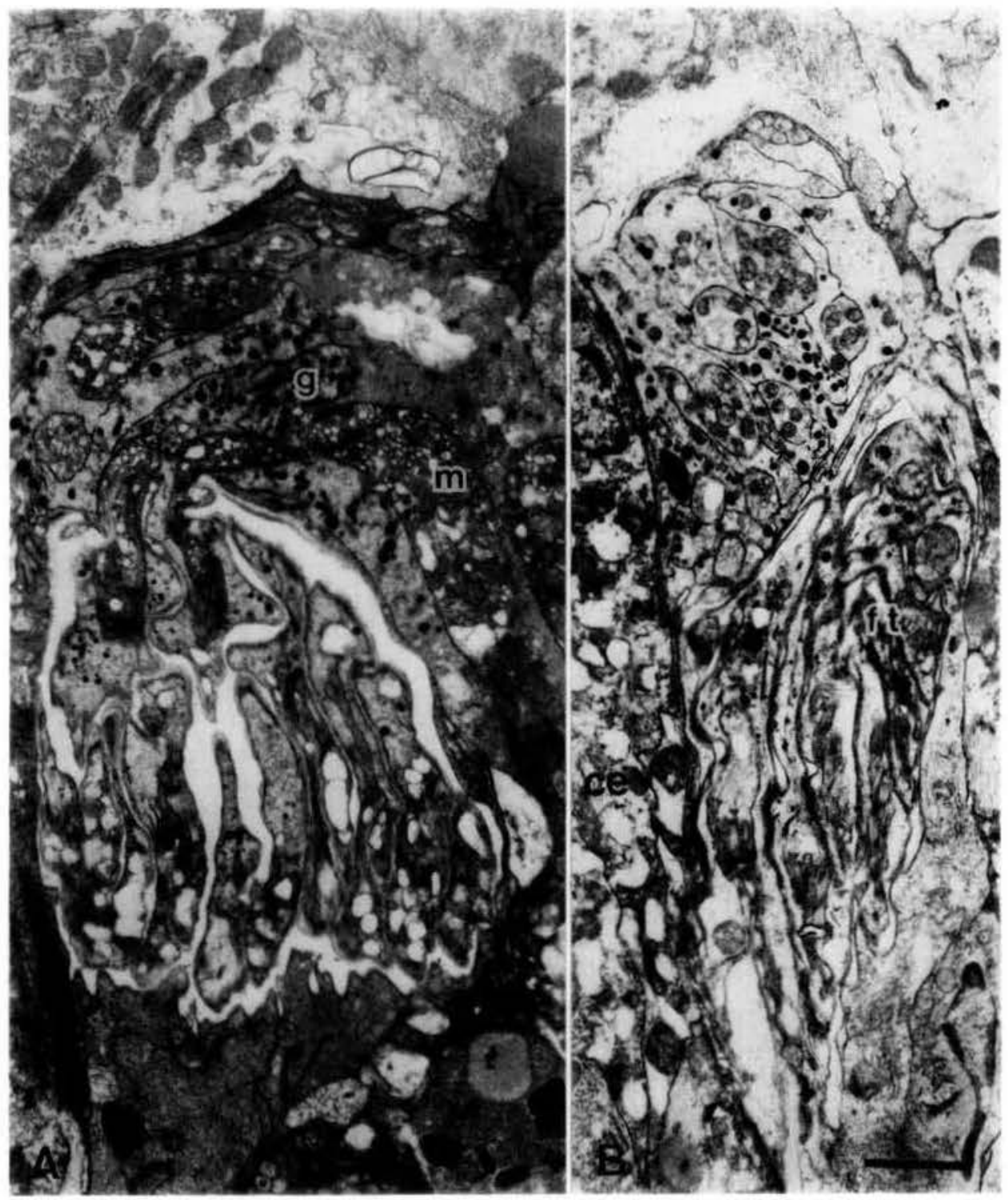

Fig. 7. Proximal portions of filaments of filamentary tuft complex. A. Sagittal section (upper $=$ dorsal; left=anterior); B. Cross section (upper =dorsal; left=lateral). ce, compound eye. ft, filamentary tuft. g, granular cell. $\mathrm{m}$, mitochondria cell. Scale: $2 \mu \mathrm{m}$.

As mentioned above, the mitochondria cells have dense mitochondria (Figs 5B, 7A). These mitochondria are almost spherical, and are prominent from the perinuclear region to the narrow, dorsal apex of the cell. Clear vesicles are also abundant. The cytoplasm of the mitochondria cells generally appears to be more electron-dense than that of the granular cells if the granules are not taken into consideration (Fig, 5B). 


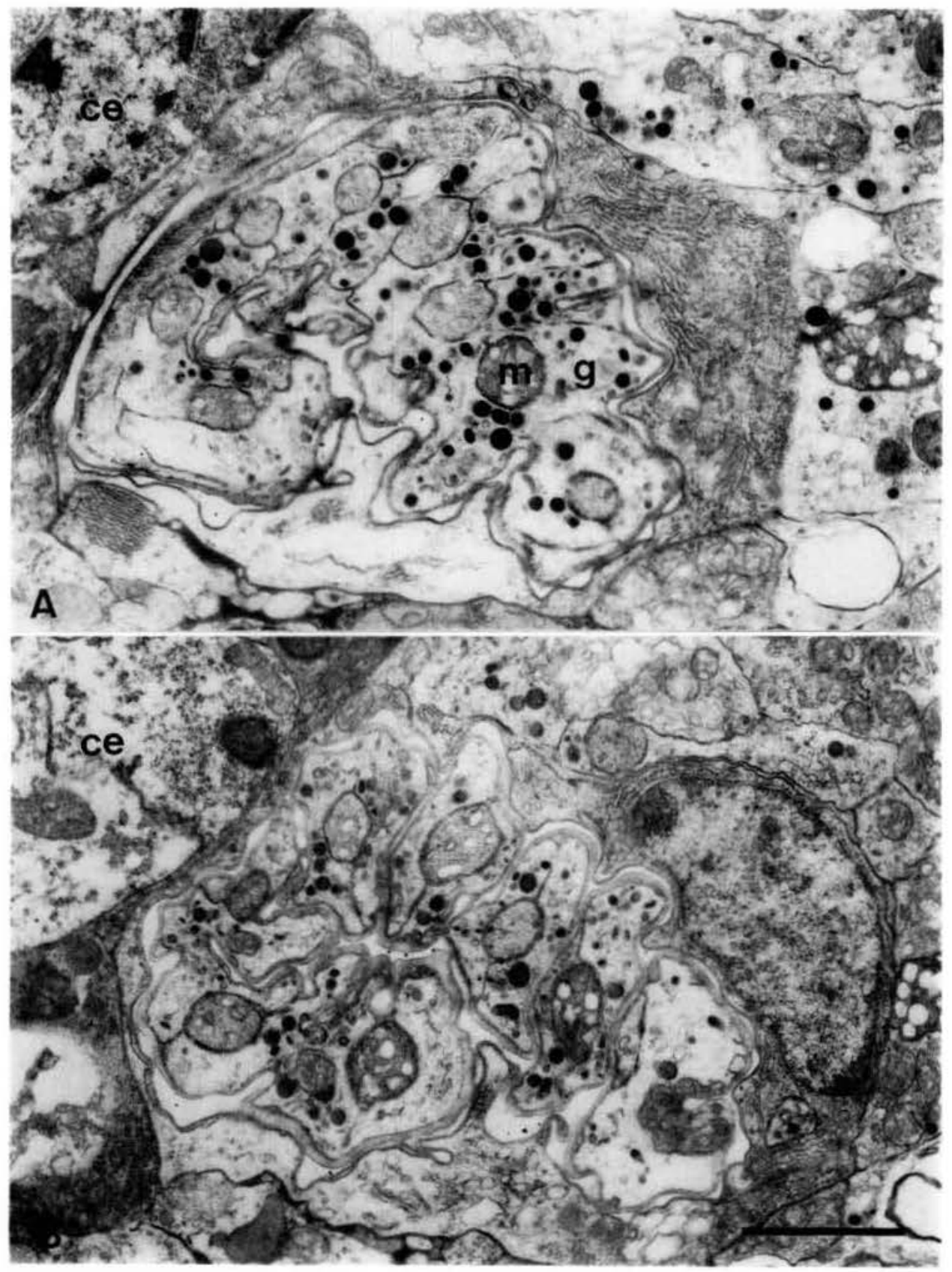

Fig. 8. Horizontal sections of filamentary tuft complex, showing differentiation of filaments (upper=lateral; left=anterior). A. Nine granular cells arranged in a incomplete loop, with eight interposed mitochondria cells (most granular cells becoming bipartite); B Section a little lower than A (some granular cells separated into filaments). ce, compound cye, g. granular cell. m, mitochondria cell. Scale: $2 \mu \mathrm{m}$. 
In some horizontal sections a little dorsal to the base of the filaments, nine granular cells appear to be arranged in a row and tightly border on each other (Fig. 8A). Seven mitochondria cells are inserted between the eight anterior granular cells so that each is completely surrounded by two adjacent granular cells, and another mitochondria cell is inserted within the posteriormost, ninth granular cell. This row of nine granular cells with eight, interposed mitochondria cells is markedly curved and appears as an incomplete loop in horizontal sections; its external appearance may

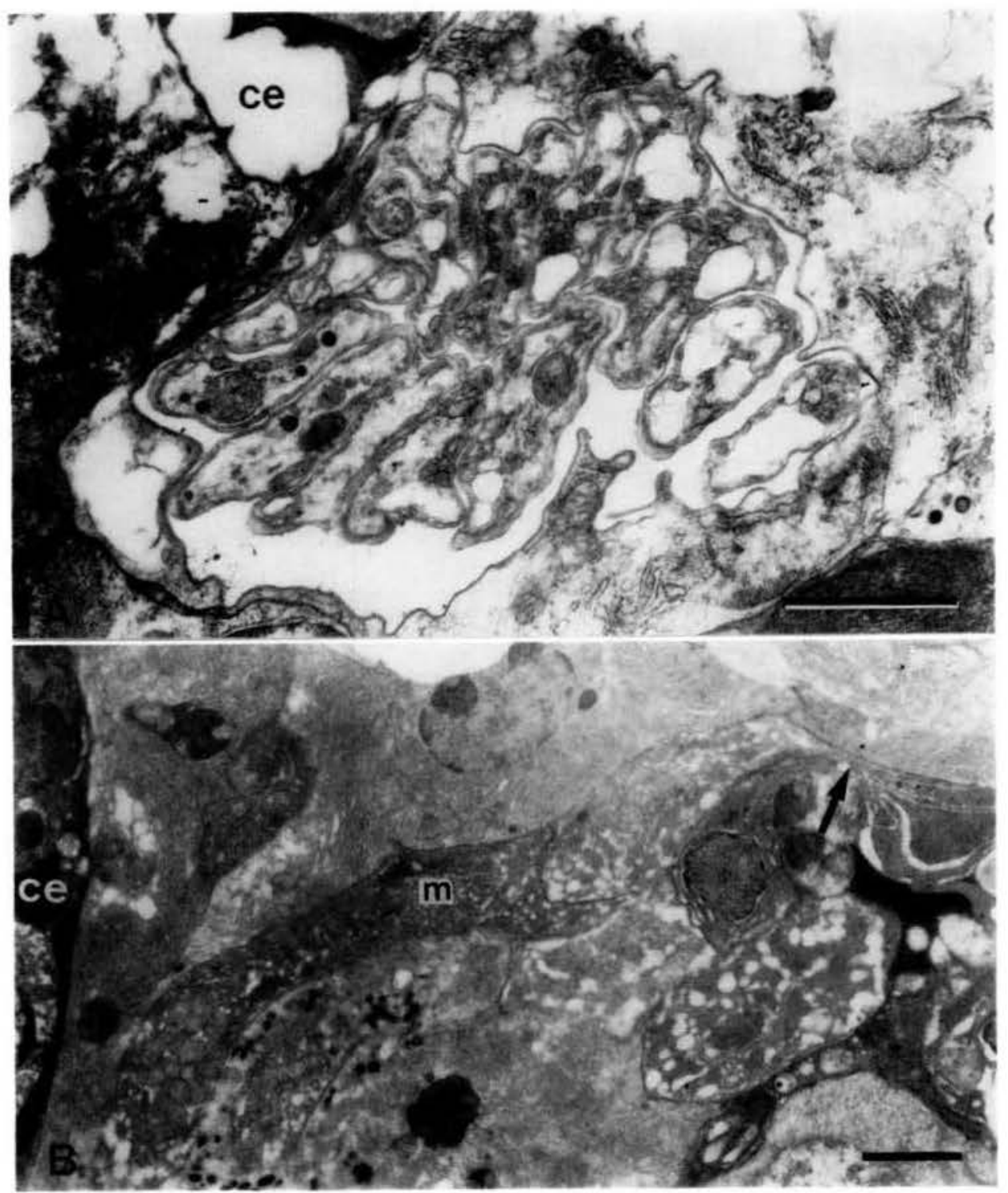

Fig. 9. A. Horizontal section of filamentary tuft, composed of 16 filaments (upper=medial: left-anterior); B. Sagittal section of a mitochondria cell with axon (arrowed) (upper= dorsal; left=posterior). ce, compound eye: $m$, mitochondria cell. Scale: $2 \mu \mathrm{m}$. 
be trough-like. The exterior of this row is covered with thin cuticle.

The two granular cells at each end of this row are different from the others apically because the former two produce only one apical filament while the remainder produce two filaments each, as described below. Each of the seven, middle granular cells is constricted by a longitudinal furrow along both of its free surfaces (Fig. 8B). These furrows become deeper ventrally, and finally divide each cell into two subcylindrical parts. Here, the original borders between these granular cells are still unchanged, and the mitochondria cells remain inserted as described above. More ventrally, the mitochondria cells terminate; the connections between all the granular cells become loose and they form free filaments, sixteen in all (Fig. 9A), one each from the end cells of the row, two each from the rest. The filaments are covered

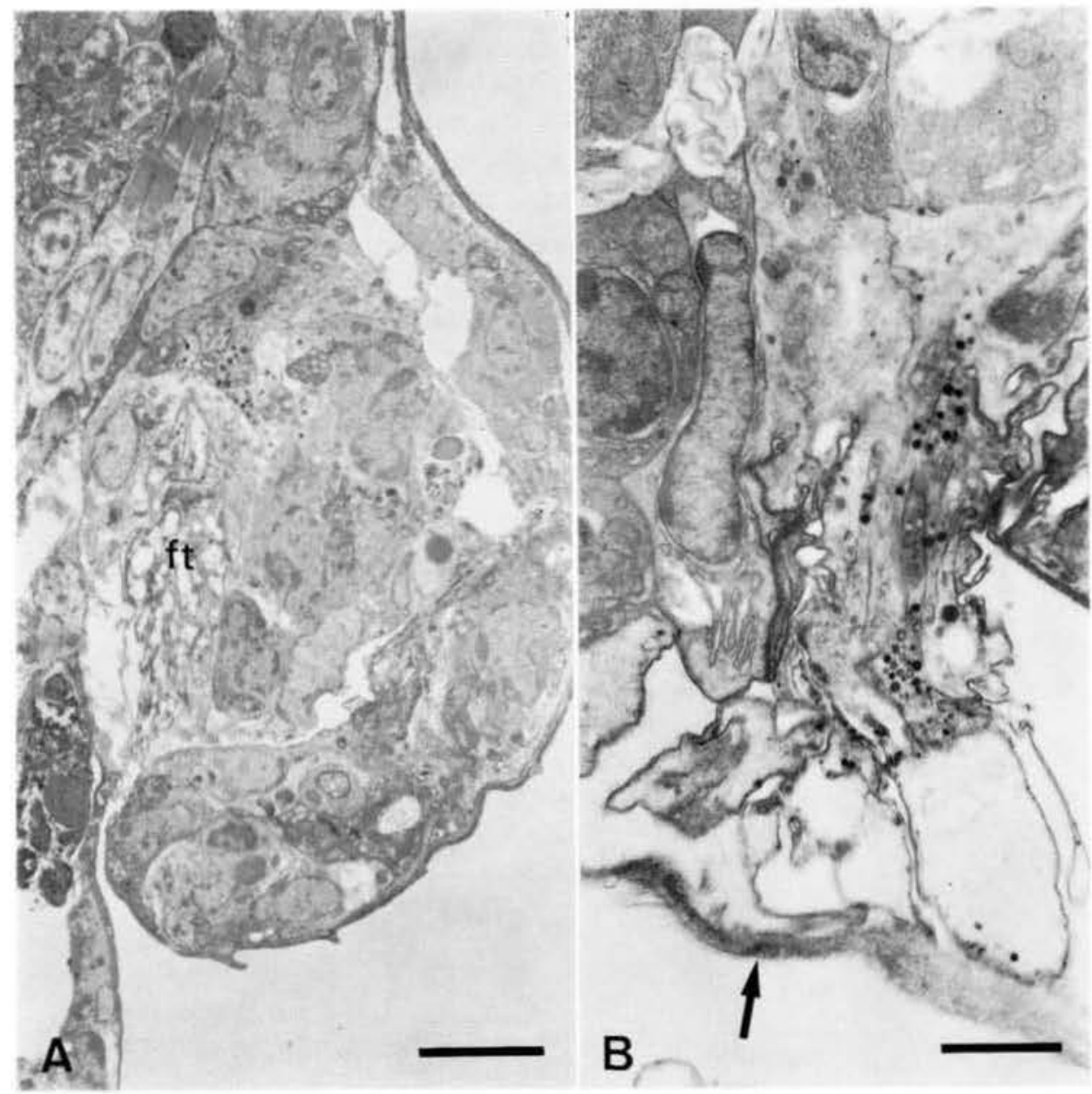

Fig. 10. A. Cross section showing general form of filamentary tuft complex (upper=dorsal; left $=$ medial $)$; B. Cross section of a last stage nauplius, showing a protruded filamentary tuft outside cyprid carapace (upper $=$ dorsal; left $=$ medial; arrow indicating faciotruncal integument). $\mathrm{ft}$, filamentary tuft. Scales: $\mathrm{A}, 5 \mu \mathrm{m} . \mathrm{B}, 2 \mu \mathrm{m}$. 
with thin cuticle. It is not determined whether the cuticle has secretory pores. The filaments are the same in their internal structure, almost filled with vacuoles (? artifact) except for short, proximal portions with granules.

In the fifth or last naupliar stage, the filamentary tufts are markedly exposed outside the cyprid carapace (Fig. 10B). A cylindrical column above the point of emergence of the filaments is exposed, although this part is normally situated deep inside the carapace in the cyprid stage (Fig. 9A). The filaments reach the naupliar faciotruncal integument (for terminology see Itô, 1987c) and spread over its internal surface. The granular cells have electrondense granules as those in cyprid stages, but their main, somatic portions inside the body are smaller than the counterparts in the cyprid stages. The mitochondria cells also appear to be less well-developed.

\section{Discussion}

Judging from its internal morphology and associated structures in general (e.g., lamellar structures made of projections of cilia with a $9+0$ microtubule array), as well as its position (Fig. 11), there is no doubt that the bifurcate paraocular process is not such an appendage as the second antenna but an external portion of the organ of Bellonci (Itô \& Takenaka, 1987). Itô (1985) proposed, and Grygier (1987c) supported, a homology between the paraocular process in facetotectan cyprids, the frontal filament in cirripedes, and the anterior filament on the eyestalks of an unusual ascothoracid larva described by Grygier (1983a). The present study has demonstrated this homology at least in part. The organ of Bellonci and its possible

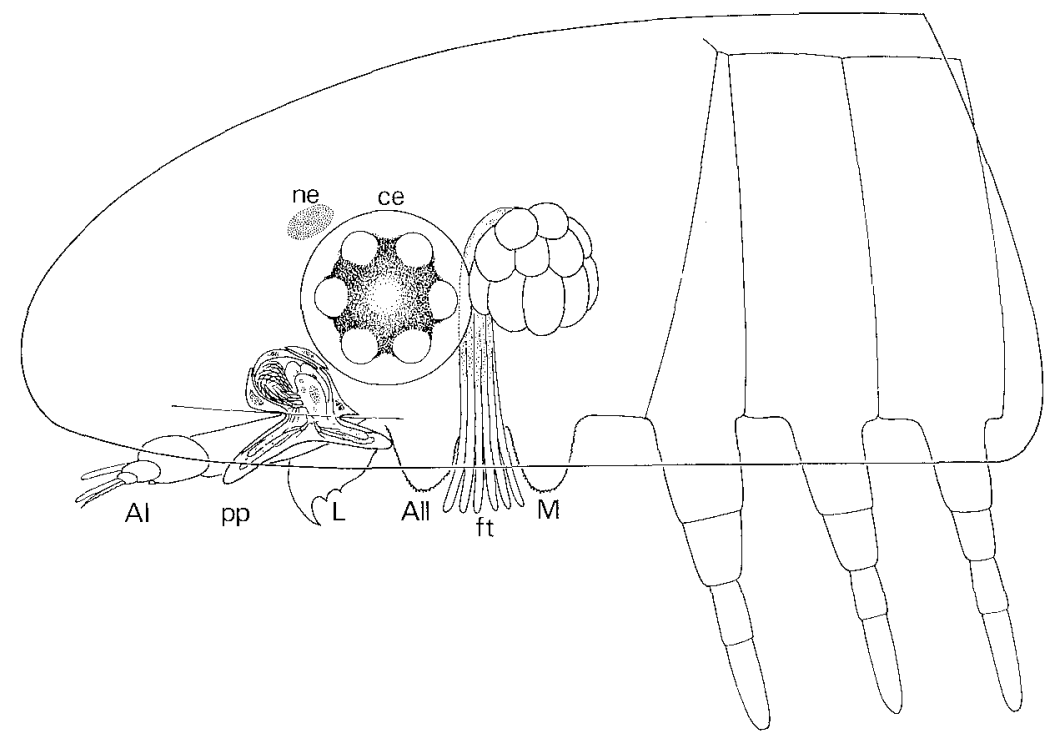

Fig. 11. Diagram to show general arrangements of the organ of Bellonci with a bifurcate paraocular process and the filamentary tuft complex of a facetotectan cyprid. AI, first antenna. AII, second antenna. ce, compound eye. ft, filamentary tuft. $\mathrm{L}$, labrum. $M$, mandible. ne, nauplius eye. pp, paraocular process. 
homologs are now known to occur in various crustaceans, not only in maxillopodans but also in malacostracans (for an extensive review see Walker, 1974).

Like facetotectans, barnacles and rhizocephalans have well-developed, external portions of this organ, usually referred to as the "frontal filament" (Kauri, 1962, 1966; Walker, 1974; $\mathrm{H} \phi \mathrm{eg}, 1985)$. In these cirripedes, the frontal filament is present even in early naupliar stages, though facetotectans have no such, externally developed, frontal filaments in any naupliar stage (Bresciani, 1965; Schram, 1970, 1972; Itô, 1986, 1987a). Facetotectan nauplii seem to have rudiments of the organ of Bellonci internally because Elofsson (1971) reports that his specimens of nauplius y had "a presumed filamentous base of the SPX-organ" connected with anlagen of cyprid compound eyes. Although Grygier (1987c) describes "papilliform frontal filaments" in his type VI nauplius y, and similar structures are present in most ascothoracid nauplii (Grygier, 1987a and references therein), it is undetermined ultrastructurally whether they are genuine frontal filaments as an external portion of the organ of Bellonci.

In the frontal filament complex of barnacle nauplii examined by Walker (1974) in detail, its vesicular part that involves dense ciliary projections is located within the body, and there is no nucleus within the external filament. The external filament contains extensions of hypodermal cells, dendrites with or without cilia, and ciliary projections. It is apparent that the external filament in the barnacle nauplii is equivalent to the paraocular process in the facetotectan cyprid, despite the prominent difference in their external appearance, i.e., the former is a simple, unbranched filament, the latter is a bifurcate process. Due to artifacts in the sections the present study is insufficient to discuss further ultrastructural details of this organ in the facetotectan cyprids and barnacle nauplii. However, it reveals a clear difference in their ultrastructure. The cilia in the barnacle organ are accompanied by rootlets (Walker, 1974), but no rootlets are detected in the facetotectan organ (Fig. 4B). Dudley (1972) reports a similar observation that the cilia in the "cephalic sensory receptor" of a parasitic copepod are not accompanied by rootlets.

The frontal filament of rhizocephalan cyprids appear to be almost filled with complex, lamellar or reticulate structures $(\mathrm{H} \phi \mathrm{eg}, 1985)$. In the facetotectan cyprids here examined, similar structures are recognized as a mass which is located close to the base of the paraocular process but which does not apparently extend into it. Although rhizocephalan cyprids have no compound eyes, barnacle cyprids, like usual facetotectan cyprids (for an unusual form see Itô, 1986d), have well-developed compound eyes and the frontal filaments arise from the short eye stalks (Walker \& Lee, 1976). This situation of the frontal filament is similar to that of the paraocular process of facetotectan cyprids. Hence, it would be of particular significance to know the fine structure of the frontal filaments in barnacle cyprids. In contrast to the detailed studies of naupliar structures cited above, no published information on the internal ultrastructure of this organ is now available for barnacle cyprids.

It is highly possible that the organ of Bellonci, inclusive of the frontal filament, of naupliar barnacles is somewhat different in fine structure from its counterpart in 
the cyprids; at least its situation is known to change greatly between the last naupliar (metanaupliar) and cyprid stages (Walker, 1974). Known features of the organ of Bellonci in barnacle nauplii might represent only an incomplete development of this organ. Although possible functions of this organ in barnacles have been discussed by Walker (1974) based upon his detailed studies on nauplii, this organ might not actually function through the naupliar stages. In a parasitic copepod, the "end organ B" of a cephalic sensory receptor, which seems to be a part of the organ of Bellonci, is known to occur even in early larval stages, but it reaches its greatest development in the second copepodid stage, which infects an ascidian host (Dudley, 1972). Hence, it is likely that the organ in barnacles also changes in its structure (function as well) during development.

On the other hand, the function of this organ in facetotectans is unknown. It might function to search for their hosts or the substrata to which they will attach. However, it is still uncertain whether the described features represent the final or completed structure of this organ because known facetotectan cyprids are not adult and the adults are unknown at the present (Itô, 1987a).

According to Grygier (1987c), a facetotectan cyprid that he examined has an attached, short lobe on the base of the usual, bifurcate process. In contrast to his specimen, our specimens had no such "short basal lobe," although corrugations were recognized. Grygier (1987c) suggests that this lobe is equivalent to the basal appendix in ascothoracid antenna-frontal filament complex (Grygier, 1987b). The basal appendix was formerly interpreted as a vestigial compound eye by Grygier (1984), but now it is suggested to involve the vesicular part of the organ of Bellonci (Grygier, 1987c). As mentioned above, the vesicular part of the organ of Bellonci in the facetotectan cyprids here examined is located within the body. A comparative, ultrastructural study is required to determin this homology.

There is no doubt that the external portion of the organ of Bellonci is variable in form. It is not necessarily a simple, unbranched structure like the frontal filament in cirripedes. It may be bifurcate or trifurcate. In addition to the bifurcate form exemplified by the paraocular process in usual facetotectan cyprids, bifurcate, preantennular processes in nectiopodan remipedes (Yager, 1981; Schram et al., 1986) have recently been understood as an external portion of the organ of Bellonci (Itô \& Takenaka, 1987). The so-called second antennae (Newman, 1974; Grygier, 1981, 1983), antenna-vestigial eyestalk complexes (Grygier, 1984), or antenna-frontal filament complexes (Grygier, 1987b) in ascothoracids exhibit trifurcate or even tetrafurcate forms. In this repsect, the posterior or dorsal ramus of these structures in ascothoracid males has recently been explained as being a distinct structure, which "arises next to the ventral ramus, not from a common base" (Grygier, 1987c). However, his illustration (Grygier, 1987c, Fig. 6A) does not seem to clearly demonstrate it, especially the important point that the posterior ramus does not arise from a common base. A more persuasive demonstration is necessary.

In ostracods the paired organs appear to fuse with each other and form a single median process, which has been known as the rod-shaped organ (Andersson, 1977). 
This is another case showing the variability of the organ of Bellonci.

The postocular filamentary tuft is now understood as cuticle-lined, external portions of certain cells that are parts of a prominent organ, probably a gland, located within the cephalon (Fig. 11). The filamentary tuft is neither the second antenna nor the mandible because, as Grygier (1987c) suspected, the naupliar second antenna and mandible remain on the cyprid cephalon as prominent, papillary processes located respectively anterior or posterior to the filamentary tuft (Fig. 5A). One of us (T.I.) has often observed that these papillary processes are prominent when the animal molts to the cyprid stage, but they soon begin to shrink, and become inconspicuous within a few hours. In Grygier's (1987c) sectioned cyprid, the papillary processes are very small, and the front one is located directly medial to the base of the filamentary tuft. These differences between our material and Grygier's probably reflect a difference in their development.

The filamentary tuft complex, of which the filamentary tuft is the external portion, is situated just posterior to each compound eye, and is composed of two cell types. In these two aspects, the filamentary tuft complex agrees with cement glands known in barnacle cyprids. The paired cement glands of Balanus balanoides lie ventrolaterally within the cyprid carapace, just posterior to the compound eyes, and are composed of two cell types (Walker, 1971). In the cement gland of this barnacle, the two types of cells are called the " $\alpha$ cell" and " $\beta$ cell." The $\alpha$ cell is characterized by a high content of electron-dense granules as well as by an abundance of rough ER. These characteristics are the same as in the granular cells of the facetotectan filamentary tuft complex. On the other hand, the $\beta$ cell is characterized by membrane-bound vacuoles with reticulated, electron-dense material, small quantities of rough ER, and a few mitochondria between the vacuoles. The $\beta$ cell is possibly equivalent to the mitochondria cell in the facetotectan organ, although its organelles are somewhat different in detail as discussed later. The $\alpha$ and $\beta$ cells are columnar, as are the granular and mitochondria cells.

The present study revealed a general similarity between the filamentary tuft complex and the cement gland, but it revealed differences too. The granules in the $\alpha$ cells of the cement gland have a "reticulum of coarse or fine mesh" (Walker, 1971), while the granules in the filamentary tuft complex do not have such an internal structure. A more prominent difference occurs between the $\beta$ cells and mitochondria cells. The $\beta$ cells have "a few mitochondria" (Walker, 1971). This feature is in clear contrast to the mitochondria cell because the latter has dense mitochondria. In general appearance, especially in the richness of mitochondria, the mitochondria cells are rather similar to the epithelial cells of certain excretory organs in different animals (Welsch \& Storch, 1976). These differences between the cement gland and filamentary tuft complex might imply a difference in their function, even if they are homologous.

Cement glands similar to those in barnacles are known in rhizocephalan cyprids, too. According to Hфeg (1985), the cyprid of Lernaeodiscus porcellanae (Müller) has 
two types of cement glands, i.e., the cypris gland and kentrogon gland. Each consists of eight cells that have dense secretion vacuoles. They have abundant rough $\mathrm{ER}$ as in the $\alpha$ cell of the barnacle cyprid as well as in the granular cell of the facetotectan cyprid. However, no cell that is equivalent to the $\beta$ cell or mitochondria cell is recognized in the cement glands of this rhizocephalan cyprid.

The cement glands in cirripedes are each associated with a duct that leads to an opening located at the tip of the first antenna (Walker, 1971; Hoeg, 1985). Moreover, the first antennae, especially in barnacles, are known to be equipped with complex, surface structures around this opening (Walker \& Lee, 1986; Walker \& Yule, 1984). In contrast, the facetotectan filamentary tuft complex has no such duct; instead, this organ is partially exposed outside the body as if it discharged the secretory substance directly into the water through its filamentary processes. The actual function of the filamentary tuft is an open question because the most crucial point, i.e., whether or not the organ at the cypris stage exhibits its final form, remains uncertain.

Grygier (1987c) tries to homologize the posterior ramus of the ascothoracid organ formerly called the "antenna-frontal filament complex" with the filamentary tuft of facetotectans. However, it is apparent that precise information on this ascothoracid organ is still too poor despite the long dispute about its identity since the time of Okada $(1926,1938)$. What is now required is an ultrastructural study of the ascothoracid organ using modern techniques.

In contrast to the common occurrence of paraocular processes in facetotectans, filamentary tufts have not been recognized to occur in all facetotectans; Hansenocaris rostrata Itô and $H$. tentaculata Itô seem to lack them (Itô, 1985, 1986c). One of us (T.I.) has observed that filamentary tufts are most apparent in cyprids just after the molt. This observation would be easily understood from a fact presented above; the filamentary tuft undergoing formation inside the naupliar integument is greatly protruded beyond the cyprid carapace (Fig. 9B). It is probable that those cyprids without externally recognizable filamentary tufts are ones observed long after their last molt. However, it is difficult to apply this to the case of $H$. tentaculata. The carapace of this species is wide open ventrally and the ventral surface of its cephalon can be fully seen (Itô, 1986c); nevertheless, no trace of filamentary tufts can be seen. Either the filamentary tufts were completely withdrawn into the cephalon or they were absent originally. In contrast, the long stalk of the filamentary tuft reconstructed from sections by Grygier (1987c) and the extremely protruded filamentary tuft observed by Itô (1985, Fig. 1B) in a specimen of $H$. pacifica may indicate that the specimens had recently molted.

Grygier (1987c) reports only 13 filaments in the filamentary tuft of a facetotectan cyprid from Denmark. Presumably it has fewer glandular cells than the present specimens, or they divide differently into individual filaments. 


\section{Acknowledgments}

We express our gratitude to Professor M. Yoshida of the Ushimado Marine Laboratory, who understood the significance of this study and made our joint work possible. The major part of this work was carried out using the facilities of the Ushimado Marine Laboratory. Sincere thanks are due to Dr. M.J. Grygier who critically read the manuscript. Drs Sh. Hiruta and K. Izawa helped us with literature. This study is supported in part by a Grant-in-Aid for Scientific Research, No. 62540567, from the Ministry of Education, Science and Culture, Japan.

\section{References}

Andersson, A. 1977. The organ of Bellonci in ostracodes: an ultrastructural study of the rod-shaped, or frontal organ. Acta Zool. (Stockh.), 58: 197-204.

Bresciani, J. 1965. Nauplius "y" Hansen. Its distribution and relationship with a new cypris larva. Vidensk. Medd. Fra Dansk Naturh. Foren., 128: 245-258.

Dudley, P.L. 1972. The fine structure of a cephalic sensory receptor in the copepod Doropygus seclusus Illg (Crustacea: Copepoda: Notodelphyidae). J. Morph., 138: 407-432.

Elofsson, R. 1971. Some observations on the internal morphology of Hansen's nauplius y (Crustacea). Sarsia, 46: 23-40.

Grygier, M.J. 1981. Gorgonolaureus muzikae sp. nov. (Grustacea: Ascothoracida) parasitic on a Hawaiian gorgonian, with special reference to its protandric hermaphroditism. J. Nat. Hist., 15: $1019-1045$.

- 1983a. A novel, planktonic ascothoracid larva from St. Croix (Crustacea). J. Plankt. Res., 5: 197-202.

- 1984. Comparative morphology and ontogeny of the Ascothoracida, a step toward a phylogeny of the Maxillopoda. Pp. 1-417. Ph. D. Thesis, University of California at San Diego.

- 1987a. Nauplii, antennular ontogeny, and the position of the Ascothoracida within the Maxillopoda. J. Crust. Biol., 7: 87-104.

. 1987b. Reappraisal of sex determination in the Ascothoracida. Crustaceana, 52: 149-162. - 1987c. New records, external and internal anatomy, and systematic position of Hansen's y-larvae (Crustacea: Maxillopoda: Facetotecta). Sarsia, 72: 261-278.

$\mathrm{H} \phi \mathrm{eg}$, J.T. 1985. Cypris settlement, kentrogon formation and host invasion in the parasitic barnacle Lernaeodiscus porcellanae (Müller) (Crustacea: Cirripedia: Rhizocephala). Acta Zool. (Stockh.), 66: $1-45$.

Itô, T. 1985. Contributions to the knowledge of cypris y (Crustacea: Maxillopoda) with reference to a new genus and three new species from Japan. Sp. Publ. Mukaishima Mar. Biol. Stat., 1985: 113-122.

- 1986a. Three types of "nauplius y" (Maxillopoda: Facetotecta) from the North Pacific. Publ. Seto Mar. Biol. Lab., 31: 63-73.

- 1986b. The phylogeny and origin of Copepoda (Crustacea). Pp. i-ii, 1-31. The Seto Marine Biological Laboratory, Kyoto University, Shirahama. (In Japanese)

- 1986c. A new species of "cypris y" (Crustacea: Maxillopoda) from the North Pacific. Pubi. Seto Mar. Biol. Lab., 31: 333-339.

- 1986d. Problems in the taxonomy of nauplius y and cypris y (Crustacea). Zool. Sci., 3: 1111 (Abstract).

- 1987a. Y.larvae-enigmatic crustacean larvae. Ann. Rep. Seto Mar. Biol. Lab., 1: 5258. (In Japanese)

- 1987b. Three forms of nauplius y type VIII larvae (Grustacea: Facetotecta) from the North Pacific. Publ. Seto Mar. Biol. Lab., 32: 141-150.

- 1987c. Proposal of new terminology for the morphology of nauplius y (Crustacea: Maxillopoda: Facetotecta), with provisional designation of four naupliar types from Japan. Zool. Sci., 4: 913-918.

—. \& M. Takenaka 1987. Identification of bifurcate paraocular process and postocular 
filamentary tuft of "cypris y" (Crustacea: Maxillopoda: Facetotecta). Zool. Sci., 4:1113 (Abstract).

Kauri, T. 1962. On the frontal filaments and nauplius eye in Balanus. Crustaceana, 4: 131-142. 1966. On the sensory papilla X organ in cirriped larvae. Ibid., 11: 115-112.

Newman, W.A. 1974. Two new deep-sea Cirripedia (Ascothoracica and Acrothoracica) from the Atlantic. J. Mar. Biol. Ass. U.K., 54: 437-456.

Okada, Y.K. 1926. Contribution a l'etude des Cirripédes ascothoraciques. II. Note sur l'organisation de Synagoga. Bull. Mus. Hist. Nat., Paris, 32: 69-73.

__ 1938. Le Cirripédes ascothoraciques. Trav. Stat. Zool. Wimereux, 13: 489-514, pl. XXIV.

Schram, T.A. 1970. On the enigmatical larva nauplius y type I Hansen. Sarsia, 45: 53-68.

- 1972. Further records of nauplius y type IV Hansen from Scandinavian waters. Ibid., 50: $1-24$.

Schram, F.R., J. Yager \& M.J. Emerson 1986. Remipedia. Part 1. Systematics. San Diego Soc. Nat. Hist., Mem., 15: 1-60.

Walker, G. 1971. A study of the cement apparatus of the cypris larva of the barnacle Balanus balanoides. Mar. Biol., 9: 205-212.

- 1974. The fine structure of the frontal filament complex of barnacle larvae (Crustacea: Cirripedia). Cell Tiss. Res., 152: 449-465.

- \& V.E. Lee 1976. Surface structures and sense organs of the cypris larva of Balanus balanoides as seen by scanning and transmission electron microscopy. J. Zool. (Lond.), 178: 161-172.

- \& A.B. Yule 1984. Temporary adhesion of the barnacle cyprid: The existence of an antennular adhesive secretion. J. Mar. Biol. Ass. U.K., 64: 679-686.

Welsch, U. \& V. Storch 1976. Comparative Animal Gytology \& Histology. Pp. i-ix, 1-343. Sidgwick \& Jackson, London.

Yager, J. 1981. Remipedia, a new class of Crustacea from a marine cave in the Bahamas. J. Crust. Biol., $1: 328-333$. 